\title{
The child's body without fluid: mother's knowledge and practices about hydration and rehydration in Salvador, Bahia, Brazil
}

\author{
Cristina Larrea-Killinger, Araceli Muñoz
}

- Additional material is published online only. To view please visit the journal online (http://dx.doi.org/10.1136/jech2012-201919).

Department of Social Anthropology, University of Barcelona, Barcelona, Spain

\section{Correspondence to} Dr Cristina Larrea-Killinger, Department of Social

Anthropology, University of Barcelona, Montalegre, 6, Barcelona, 08001, Spain; larrea@ub.edu

Received 10 September 2012 Revised 22 February 2013 Accepted 24 February 2013

To cite: Larrea-Killinger C, Muñoz A. J Epidemiol Community Health Published Online First: [please include Day Month Year]

doi:10.1136/jech-2012-

201919

\begin{abstract}
Background The aim of this article was to anthropologically analyse knowledge and practices about hydration and rehydration in a specific ethnographic context, where diverse therapies are combined to treat and take care of child diarrhoea as part of a wider social process that circumscribes transactions between self-care and biomedicine.

Methods Ethnographic data from a qualitative study in the neighbourhood of Nova Constituinte (Salvador, Bahia) which was part of an interdisciplinary project aimed at epidemiologically evaluating an environmental sanitation programme. These data results from a series of in-depth interviews of 29 interviewees and field observations collected over two stages (1997/1998-2003/2004).
\end{abstract}

Results Knowledge about hydration and rehydration is practical knowledge that demonstrates some of the cultural limits of dehydration in terms of the normality or pathology criteria related to child diarrhoea. This knowledge belongs to local interpretations, treatment experiences and the care that mothers provide in relation to their child's diarrhoea. We observed a process of medicalisation in the discourse about hydration and self-care.

Conclusions Unlike rehydration, hydration is structural to self-care processes. While the former constitutes a way of alleviating diarrhoea, the latter is a type of care centred on healing. The difference between these practices does not lie in the type of remedies used but in the meaning attributed to them and the way they are combined.

\section{INTRODUCTION}

In the late 1970s, the WHO developed oral rehydration therapy (ORT) and with UNICEF, began several vertical dissemination programmes aimed at combating child mortality related to diarrhoea. In 1980, they initiated a control programme specifically designed to treat this type of disease. ${ }^{1}$ When the WHO realised that the child death rate had dropped from $25 \%$ of the child population in 1960 to $18 \%$ in 2005 , this inexpensive, easy-to-prepare, easy-to-obtain ORT was seen as one of the 20th century's major discoveries. ${ }^{2}$ Between 1979 and 1992, the number of saline solution packets issued to Third World countries rose from 51 to 800 million per year. ${ }^{3}$ During this period, primary health providers were in charge of recommending the provision of packets through educational programmes run by community health agents.

Despite the great success achieved till date, ${ }^{4}$ diarrhoea still remains the second leading cause of global child mortality. Given that the fourth Millennium Development Goal aims to reduce child mortality, in 2009 the WHO published a statement about the growing need to resume research on childhood diarrhoea to improve access to ORT and zinc supplements. ${ }^{5}$

In the 1980s, anthropological work on childhood diarrhoea, dehydration and rehydration focused on an analysis of ORT and oral rehydration solution. ${ }^{6}$ Many studies emphasised the ethnomedical approach, ${ }^{7-9}$ applied rapid ethnographic methods ${ }^{10}$ to analyse the effectiveness of medical campaigns, ${ }^{11-13}$ examined the potential role of popular healers as effective mediators in the spread of these therapies ${ }^{14-17}$ and described how mothers used these therapies. ${ }^{18} 19$ Only two anthropological studies focused on the cultural meanings of dehydration. ${ }^{20}{ }^{21}$ During the same period, other qualitative research projects explored the treatments used for cases of diarrhoea and the beliefs related to these. Households ${ }^{22}$ and maternal ideas ${ }^{23}$ were the focus of analysis.

In the 1980s, the Northeast region in Brazil had one of the highest child death rates. ORT therapies began to be analysed in order to determine whether they were effective as a means to control child mortality and morbidity in acute episodes of diarrhoea. $^{24} 25$ Gastroenteric diseases and various types of dysentery feature as the main causes of child mortality according to several studies which focused on mothers' perceptions. ${ }^{26}$

In the 1990s, certain published papers evaluated the positive impact of ORT on reducing morbidity and mortality in childhood diarrhoea. ${ }^{27} 28$ Anthropological work regarding diarrhoea set aside the role of the healer and became more aware of the mother's role in selecting treatment. ${ }^{29}$ The outbreak of the 1991 cholera epidemic in Latin America led the WHO to prioritise international policies that involved improving access to drinking water, investment in sanitation and the promotion of healthy behaviour. ${ }^{30}$

Between the 1990s and the first decade of the millennium, a great deal of epidemiological and interdisciplinary research was carried out. ${ }^{31}$ Anthropological and epidemiological methods were applied to analyse hygiene behaviour within households. $^{32} 33$ Some focused on evaluating health education programmes and measures ${ }^{34}$ such as hand-washing with soap ${ }^{35}{ }^{36}$; sanitation measures, such as sewage system implementation ${ }^{37}$ or the use of latrines. ${ }^{38}$ The study of environmental risk factors on the development of childhood diarrhoea $^{39}{ }^{40}$ became significant. 
In the same period, epidemiological evaluations of the oral rehydration dissemination programme continued to be published. ${ }^{41} 42$ Qualitative studies about diarrhoea focused on selfcare $^{43}$ caretakers' ${ }^{44}$ perspective and hygiene habits within households, ${ }^{45}$ as well as on the introduction of zinc tablets to complement ORT. ${ }^{46}$ Anthropological studies continued to focus on mothers' beliefs and practices about diarrhoea. ${ }^{47}$

The aim of this article was to anthropologically analyse knowledge and practices related to dehydration, hydration and rehydration in a deprived urban peripheral neighbourhood in Salvador (Bahia, Brazil). The article covers two stages of fieldwork: the first stage includes the period from 1997 to 1998 , while the second stage runs from 2003 to 2004. The starting point is an analysis of mothers' discourses about their experience of the care and treatment of childhood diarrhoea. A combination of various therapies is analysed as part of a wider social process involving transactions between the self-care and biomedical models. ${ }^{48}$

In the late 1990s an environmental sanitation intervention took place in the city. An interdisciplinary approach was used to assess epidemiological effects in reducing the morbidity associated with childhood diarrhoea. ${ }^{49} 50$ Other interventions, such as the implementation of the Family Health Program ${ }^{51}$ and its impact on reducing child mortality, ${ }^{52}$ were also analysed.

We believe that hydration and rehydration are practical skills that reveal certain cultural limits in relation to dehydration. These skills are part of the local understanding and experiences that mothers acquire to perceive, relieve, treat and cure childhood diarrhoea. Childhood diarrhoea, which is perceived as a common disorder, requires more in-depth qualitative studies during a long period of time from the mother's point of view in order to better understand the integration of self-care practices, self-medication and biomedical care.

Dehydration is a central element in developing normality and pathology criteria. This article analyses the aforementioned skills and practices as part of a specific social process. ${ }^{53}$ Priority is given to three topics: the social and cultural dimensions of childhood diarrhoea, ${ }^{54}$ the social experience ${ }^{55}$ of the dehydrated body and the medicalisation ${ }^{56} 57$ of self-care. Local world of social experience is a determinant of the suffering and illness process.

\section{METHODS}

The results presented in this paper are based on the qualitative analysis of ethnographic data coming from an anthropological study of childhood diarrhoea and sanitation in Nova Constituinte, a Salvador (Bahia) periurban district. This study was part of an interdisciplinary epidemiological assessment project about the impact of the 'Bahia Azul' environmental sanitation programme, ${ }^{58}$ in which the topic of the diarrhoea was central in the investigation in regard to the absence of sanitation, and the hydration and dehydration were part of the beliefs on diarrhoea. Ethnographical data of hygienic behaviours were not explored in this paper.

In this specific ethnographic context, the article analyses, through the mothers' narratives, the knowledge and practices of hydration and rehydration, where diverse therapies are combined to treat and take care of child diarrhoea as part of a wider social process that circumscribes the transactions between selfcare and biomedicine's explanatory models. ${ }^{59}$ So, mothers' explanatory models ${ }^{60}$ show their beliefs about diarrhoea and about what can happen as a result, when they should intervene, and the therapeutic practices to prevent and treat diarrhoea (hydration and rehydration) (tables 1 and 2).

\section{RESULTS}

\section{Nova Constituinte periurban district}

In this research, the historical time period is significant because of the positive changes that occurred in the neighbourhood during this time. First, a degree of urban sanitation development was seen in the construction of sewers (1999) and the implementation of this system (2003). Moreover, primary healthcare coverage was expanded through the construction of the local health centre (2003) and the implementation of the Family Health Program (2004). This programme involved the training and mediation of community health workers living in the neighbourhood. Health workers did not receive any training in ORT. Local and medical knowledge about this practice was extended

\section{Table 1 Ethnographic fieldwork}

Ethnographical data

Ethnobotanical study

Ethnographical techniques
Ethnographic data explored in this paper comes from 29 in-depth interviews and fieldwork undertaken by three female ethnographers over two stages. One of them was the principal author of this article, and also coordinated and supervised all fieldwork. The first stage covers 10 months of fieldwork in 1997 and 1998, ${ }^{61}{ }^{62}$ and the second comprises 12 months of fieldwork in 2003 and 2004 . Twenty-one months of follow-up work was undertaken between 1999 and 2002 and 2005 and 2008

The interviewees, whose choice was purposive according to the specific settings of the study, were in charge of at least one child under 5 years old. Of the 14 people in the first stage, 13 were mothers and 1 was a grandmother. The second stage included 15 people, 13 of whom were mothers, 1 was a father and 1 a grandmother (table 2). All participants were informed of the objectives of the study and their anonymity was guaranteed at all times. This anthropological study was integrated to an epidemiological research that was provided with the approval of the research ethics committee. Informed consent of the participants were required in both stages of the study, in conformity what is established in the $196 / 96$ resolution on research involving human participants

An ethnobotanical study conducted in 1998 has also been taken into account. That particular study was conducted with the help of a biologist and was the primary source for the preparation of a catalogue of medicinal herbs that was distributed around the neighbourhood (the ethnobotanical study was only carried out in the first stage, because in the second one a decrease of the use of medicinal herbs was observed and it was not considered to be necessary to do a new collection)

The ethnographic techniques included in-depth interviews on the health-disease-care process, acquisition of life histories and genealogical data, observations on health and sanitation, production of district maps and house plans, filming, photography and community activities before and after installation of the sewage system. Ethnographic data were collected in informants' homes and in the neighbourhood All audio tapes were transcribed in Portuguese by three granted students and one qualified person with experience. Later, the interviews and their narratives were analysed in order to be able to identify themes and topics and an exhaustive exploitation of the data were obtained through the software for qualitative analysis ATLAS-TI 6.2. The principal author of this paper participated in both stages as ethnographer and research coordinator. The second one helped to analyse the ethnographical data

To achieve quality, trustworthiness, rigor and dependability ${ }^{63}$ various measures were applied. Members of Research Group reviewed the transcriptions several times, participated in a systematic analysis of ethnographical data and carried out numerous discussion sessions regarding the results 
Table 2 Informants' sociodemographic characteristics

\begin{tabular}{|c|c|c|}
\hline Characteristics & $\begin{array}{l}1997 / 1998 \\
N=14\end{array}$ & $\begin{array}{l}2003 / 2004 \\
N=15\end{array}$ \\
\hline \multicolumn{3}{|l|}{ Kinship } \\
\hline Mother & 13 & 13 \\
\hline Father & 0 & 1 \\
\hline Grandmother & 1 & 1 \\
\hline \multicolumn{3}{|l|}{ Marital status } \\
\hline Cohabiting but unmarried & 12 & 7 \\
\hline Married & 0 & 2 \\
\hline Separated & 1 & 6 \\
\hline Widowed & 1 & 0 \\
\hline \multicolumn{3}{|l|}{ Age (years) } \\
\hline$<20$ & 2 & 1 \\
\hline $20-25$ & 4 & 4 \\
\hline $26-30$ & 1 & 8 \\
\hline $31-35$ & 5 & 0 \\
\hline $35+$ & 2 & 2 \\
\hline \multicolumn{3}{|l|}{ Occupation } \\
\hline Housewife & 9 & 8 \\
\hline Sells from home & 0 & 3 \\
\hline Sells on the street & 1 & 2 \\
\hline Sells in an establishment & 0 & 1 \\
\hline Domestic worker & 4 & 0 \\
\hline Pensioner & 0 & 1 \\
\hline \multicolumn{3}{|l|}{ Educational level } \\
\hline Illiterate & 1 & 0 \\
\hline \multicolumn{3}{|c|}{ Primary school(first educational level) } \\
\hline \multicolumn{3}{|l|}{ Primary I (up to 4th grade) } \\
\hline Primary I (incomplete) & 6 & 0 \\
\hline Primary I (complete) & 1 & 4 \\
\hline \multicolumn{3}{|l|}{ Primary II (from 5th to 8th grade) } \\
\hline Primary II (incomplete) & 5 & 7 \\
\hline Primary II (complete) & 0 & 0 \\
\hline \multicolumn{3}{|c|}{ Secondary school (from years 1 to 3 ) } \\
\hline Second school (incomplete) & 1 & 3 \\
\hline Second school (complete) & 0 & 1 \\
\hline
\end{tabular}

before the beginning of this research. A community centre was built during this period. This centre housed the neighbourhood association founded in 2003. A new association was established and new Pentecostal churches opened up (table 3).

The women interviewed in the first stage knew about and used rehydration techniques, although there was no health centre in the neighbourhood. During the second stage, once the poor and underused sewerage system had been implemented, positive perceptions regarding a reduction in problems such as diarrhoea and intestinal parasitosis contrasted with negative perceptions about internal inequalities related to system weaknesses. $^{64}$

\section{Childhood diarrhoea}

Our research shows that mothers perceive dehydration as a cause for alarm in relation to diarrhoea and, particularly, to a certain social criteria of severity (frequency of disease, faeces texture, etc) as well as to cultural features attributed to a normal child's body (physical conditions and behaviour). Mothers, agreeing with the medical definition, ${ }^{65}$ use the concept of diarrhoea to refer to the passage of three or more loose or liquid stools per day, or more frequently than is normal for the child.
Diarrhoea eliminates impurities from the child's body, but these impurities are not always seen as signs of disease, as discussed below. When these impurities are seen as signs of disease, recognition is made from a combination of a range of symptoms (fever; vomiting; loose, bloody or greenish stools), body changes (weight loss, skin changes, etc) and behavioural changes (weak, frail, ailing, etc) (table 4). They then deploy a series of symbolic meanings that in turn lead to various actions.

At first, mothers perceive childhood diarrhoea as a 'common problem', a 'mild', 'stupid' or 'banal' disease (besteira). The severity criteria of this syndrome are related to excess, to something that goes beyond the limits of what is considered normal. Although it is not considered dangerous, the presence of diarrhoea always leads to rehydration practices. Although these practices may be varied, intermittent and with varying degrees of intensity, they are the result of self-care processes that try to make up for the loss of body water. Other symptoms or diseases often occur alongside diarrhoea.

\section{Dehydrated body}

Dehydration is related to 'excessive loss of body water' (eg, persistent diarrhoea). Although all human activities that imply physical effort or hot weather can lead to loss of body water and thus liquid consumption, people do not perceive the ingestion of liquid due to thirst and the practice of hydration as being equal. The practice of hydration implies some specific knowledge about the limits of physical normality based on an idea of balance-if something is excessive it needs to be balanced-but drinking due to thirst is a survival instinct response. Hydration is part of a self-care process that aims to restore the body's normal condition (see online supplementary web table S1). This practice functions as a precautionary measure, since it is an attempt to prevent a disorder worsening further.

From the mothers' point of view, a child's body is much more vulnerable than that of an adult and that is why the child needs to be cared for. Nevertheless, children are not strictly supervised in their daily activities. Mothers get alarmed when their child's physical condition or behaviour is affected by a loss of vitality that they consider unusual. Some of these bodily changes express health issues. Growth disorders usually function as a worrying sign. Normal growth processes include weight gain, game playing or teething (table 5). Hydration is seen as a precautionary measure when a young child is teething, in order to avoid the potential effects of dehydration.

Beverage consumption (water, herbal tea, coffee, soft drinks, juice and saline solutions) is part of the local food culture and is also a self-care practice. It takes place in two separate social settings which correspond to different symbolic realities within Brazilian existence ${ }^{66}$ : the household, which represents the domestic sphere of privacy, trust and parental relationships and the street, which constitutes the public space that involves danger, hostility and conflict.

Mothers did not serve water at lunchtime during either of the two fieldwork stages; instead they provided fruit juice or a carbonated drink. Coffee is served hot, and is usually taken in the morning or evening. Soup is taken in the evening. Herbal teas are used to treat disorders or diseases. Plain water is used to quench thirst, but juices (figure 1) and herbal teas (figure 2) are used to hydrate and saline solutions (see online supplementary web figure S1) are used to rehydrate (table 6). Both practices are palliative treatments for dehydration.

During the first stage, weakness (corpo fraco) was treated with vitamin consumption. The idea of a vital and vigorous body was culturally associated with energy. Lack of energy owing to 
Table 3 Nova Constituinte periurban district

\begin{tabular}{|c|c|c|}
\hline & First stage (1997-1998) & Second stage (2003-2004) \\
\hline Population $\left({ }^{*}\right)$ & $\begin{array}{l}9748 \text { inhabitants (database of } 1996 \text { census obtained from the Brazilian } \\
\text { Institute for Geography and Statistics (IBGE)) }\end{array}$ & $\begin{array}{l}18077 \text { inhabitants (database of } 2000 \text { census obtained from the Brazilian } \\
\text { Institute for Geography and Statistics (IBGE)) }\end{array}$ \\
\hline Urbanisation & $\begin{array}{l}\text { Neighbourhood formed from informal land occupation that began in } \\
\text { early } 1980 \\
\text { Families from other neighbourhoods who bought land after the informal } \\
\text { land occupation } \\
\text { Families relocated by the council after being left homeless due to heavy } \\
\text { flooding or relocated after being evicted from the historic centre of the } \\
\text { city after a process of gentrification } \\
\text { Unpaved streets, opencast sewage and the accumulation of waste } \\
\text { Houses made of mud, wood and brick }\end{array}$ & $\begin{array}{l}\text { Implementation of the reform programme included in the Estatuto da } \\
\text { Cidade and distribution of Certificado Especial de Moradia (CEM) (2003- } \\
\text { 2004) } \\
\text { Property sale in some specific areas due to violence problems } \\
\text { Unpaved streets, the coexistence of opencast sewage with a damaged } \\
\text { sewerage system and sewers in good condition. Worsening condition of } \\
\text { the streets } \\
\text { Enlargement of houses and advances in their construction }\end{array}$ \\
\hline Sanitation & $\begin{array}{l}\text { Sewerage system nonexistent. Lack of surface water drainage. Beginning } \\
\text { of construction works for the sewage system } \\
\text { Houses without toilets. Some have rainwater tanks. Faeces are deposited } \\
\text { in plastic bags and thrown into the refuse }\end{array}$ & $\begin{array}{l}\text { Beginning of household connections to the sewerage system. Difficulties } \\
\text { in maintaining the network: broken pipes, network flooding and } \\
\text { obstructions in the sewers. Surface water drainage still not constructed } \\
\text { First toilet facilities }\end{array}$ \\
\hline Water supply & $\begin{array}{l}\text { Drinking water distributed across the whole area. The system is } \\
\text { inadequate due to water quality and irregular supply; sometimes there is } \\
\text { no water on several consecutive days }\end{array}$ & $\begin{array}{l}\text { Progress in the supply of drinking water with increased frequency of } \\
\text { distribution }\end{array}$ \\
\hline Refuse collection & $\begin{array}{l}\text { Inadequate refuse collection system. Existence of clandestine dumps in } \\
\text { the neighbourhood }\end{array}$ & $\begin{array}{l}\text { Progress made in the refuse collection system. Containers placed on the } \\
\text { streets and the partial elimination of clandestine dumps }\end{array}$ \\
\hline Services & $\begin{array}{l}\text { Without public transport (buses) inside the district. Nearest at } 15 \mathrm{~min} \\
\text { walking } \\
\text { Existence of community associations, community schools, a range of } \\
\text { businesses, evangelical churches and candomblé (an Afro-Brazilian } \\
\text { religion) worship houses }\end{array}$ & $\begin{array}{l}\text { First private initiative of mini-buses inside the district that was suspended } \\
\text { a few months afterwards. Introduction of a private service of motorcycles } \\
\text { inside the district } \\
\text { Construction of the health centre (2003) and beginning of the Family } \\
\text { Health Program with local } 13 \text { health workers (2004) } \\
\text { Increase in the number of evangelical churches and other establishments }\end{array}$ \\
\hline $\begin{array}{l}\text { Socioeconomic } \\
\text { characteristics }\end{array}$ & $\begin{array}{l}\text { Most women are housewives and their husbands live from informal } \\
\text { economy and small temping. Working women are usually domestic } \\
\text { workers } \\
\text { They uninterruptedly receive milk supplements from social programmes, } \\
\text { support for children under } 14 \text { so they do not have to work and grants for } \\
\text { buying butane gas }\end{array}$ & $\begin{array}{l}\text { Women combine their occupation as housewives with the informal } \\
\text { economy (selling products at home or on the street) or as domestic } \\
\text { workers. Men work in the informal economy as construction workers } \\
\text { They regularly receive the Bolsa Familia (government's programme which } \\
\text { consists of an economical aid), depending on the number of children and } \\
\text { wages (social programme of the Federal Government) }\end{array}$ \\
\hline $\begin{array}{l}\text { Health } \\
\text { characteristics }\end{array}$ & $\begin{array}{l}\text { The major child's health problems are malnutrition, diarrhoea and } \\
\text { respiratory diseases (not available epidemiological data on morbidity and } \\
\text { mortality in the neighbourhood) } \\
\text { In the district there are local treatment resources as healers (rezadeiras) } \\
\text { who pray the evil eye and fright and medicinal plants sellers (raizeras) } \\
\text { that are often required by the people } \\
\text { Despite the existence of Afro-Brazilian religious cults, priests were seldom } \\
\text { asked to solve common child's health problems such as diarrhoea and } \\
\text { respiratory diseases } \\
\text { Mothers combine self-care and self-medication practices, more that } \\
\text { health services available in the neighbouring district }\end{array}$ & $\begin{array}{l}\text { The major child's health problems are respiratory and skin diseases, as } \\
\text { indicated by community health workers. However, there are still cases of } \\
\text { malnutrition and diarrhea in some areas of the district (not available } \\
\text { epidemiological data on morbidity and mortality in the neighbourhood) } \\
\text { Health workers perform home visits for vaccinations and weight/size } \\
\text { control, programme specialist's visits, distribute prescribed drugs that are } \\
\text { arriving late and facilitate emergency and hospitalisation } \\
\text { Self-care and self-medication continue to merge with a decrease in } \\
\text { intervention of rezadeiras and raizeiras } \\
\text { Spiritual health problems, especially in adults, are required in } \\
\text { Afro-Brazilian Candomblé centres and evangelical cults }\end{array}$ \\
\hline
\end{tabular}

${ }^{*}$ Data were obtained by summing the populations living in the census tracts corresponding to this district.

excessive work or poor diet was usually treated with vitamins or increased sugar consumption. Although the word 'vitamin' is used to designate a drink made of bananas and milk, mothers chose from a wide range of vitamins bought in the pharmacy. By the second stage this habit had reduced dramatically.

In the 1990s Brazil became the third largest soft drinks market in the world. ${ }^{67}$ In 2002 , the non-carbonated beverage sector had increased by $34 \% .{ }^{68}$ Currently, fruit juices occupy $75 \%$ of the market. Soft drinks are replacing fruit powders in popularity. The success of drinks based on fruit juice is related to the persistently healthy images seen in advertising. Actually, the industry of bottled water uses the scientific principle of hydration to stimulate consumption. ${ }^{69}$

The Northeast region has $27.8 \%$ of Brazil's population and is the leading consumer of non-alcoholic drinks (20.3\%). The country has recently considered establishing a tax to reduce the consumption of sugary beverages within households. ${ }^{70}$ According to WHO standards, Brazil is the world's leading consumer of sugar. ${ }^{71}$

\section{Medicalisation of hydration}

Rehydration involves methods of care and self-medication. ${ }^{72}$ Care occurs when a mother goes to a doctor after a number of days of childhood diarrhoea and leaves the clinic with several saline solution packets. Self-medication occurs when this practice has already been learnt by mothers in the doctor-patient relationship and when packages are free and easy to obtain in health centres. This widespread practice is combined with other hydration measures and with self-medication practices, which include antibiotic pills to help reduce the severity perceived by mothers. For mothers, when certain kinds of diarrhoea begin to be classified as diseases, 'doctor's remedies' are stronger and more efficient than their own (box 1).

The use of the term 'rehydration' occurs with the use of saline solutions. These are distributed free of charge by health centres and must be dissolved in boiled water.

Thus, oral rehydration and boiled water are healing practices that have become incorporated as a result of paediatric instruction. Nevertheless, the adoption of these practices as normal 
Table 4 Mothers' perceived causes of child's diarrhoea

\begin{tabular}{|c|c|c|c|}
\hline \multicolumn{2}{|l|}{ 1997-1998 } & \multicolumn{2}{|l|}{ 2003-2004 } \\
\hline Nutrition & Social conditions & Nutrition & Growth \\
\hline Deficits, excesses, changes & Low economic status & Deficits, excesses, changes & Teething \\
\hline Food excess & Medical care & Bad nutrition & Body \\
\hline Palm oil & Reaction to injections & Lack of nutrition & Infection \\
\hline Margarine & Reaction to antibiotics & Lack of milk & Heat in the bowel \\
\hline Malnutrition & Lack of medical responsibility & Continued breastfeeding & Child behaviour \\
\hline Weaning & Growth & Preparation and conservation & Putting dirty things in the mouth \\
\hline Preparation and conservation & Teething & Greasy & Dirty hands \\
\hline Greasy & Body & Expired & Walking barefoot \\
\hline Fried & Swallowing liquid during childbirth & Spoiled & Walking barefoot through refuse \\
\hline Too much sugar & Infections & Badly cooked & Playing in the refuse and sewage \\
\hline Badly made porridge & Intestinal Infections & Badly made & Playing under the sun \\
\hline Spoiled food & Infections from breast milk & Sour & Not drinking water \\
\hline Food leftover from the & Lack of liquid & Leftover from the previous day & Adult behaviour \\
\hline previous day & Uncontrolled bowels & Cold & Lack of hygiene \\
\hline Unwashed fruit & Child behaviour & Very Hot & Lack of experience \\
\hline Problems associated with milk & Walking barefoot & 3 days out of the fridge & Lack of care \\
\hline Kind of food & Playing with hands in soil & Badly washed or unwashed food & Breastfeeding during pregnancy \\
\hline Heavy & Stepping on rubbish & Porridge leftover from the previous & Breastfeeding after coming back from the \\
\hline Strong & Eating rubbish & day & street \\
\hline Beef stew with beans & Eating bricks & Unboiled porridge & Not washing child's hands \\
\hline Calf's foot and tripe stew & Adult behaviour & Uncooked porridge & Not putting fresh clothes on the child \\
\hline (mocotó) & Irresponsible & Kind of food & Diseases \\
\hline Desserts & Lack of experience & Pork meat & Diarrhoeal diseases \\
\hline Environmental & Not giving water to child & Palm oil & Parasitic worms \\
\hline Climate changes & Allowing the child to be exposed to the sun & Vatapá (a doughy mixture of dried & Parasite attack \\
\hline Heat & Diseases & prawns, peanuts and bread) & Dysentery \\
\hline Too much heat & Diarrhoeal diseases & Acarajé (a fried ball of mashed & Dengue \\
\hline Muggy weather & Parasitic worms & black-eyed peas and dried prawns) & Intestinal infection \\
\hline Mud & Parasite attack & Avocado & Droopy belly (ventre caído or vento caído-a \\
\hline Pollution & Evil eye & Hot mango & form of diarrhoea only curable by a healer). \\
\hline Contaminated water & Droopy belly (ventre caido or vento caído- & Too many oranges & Evil eye \\
\hline Water with microbes in it & a form of diarrhoea only curable by a & Packaged milk & Susto (sickness due to fright) \\
\hline Running water & healer) & Too much coffee & Related diseases \\
\hline Unfiltered water & Dysentery & Manioc flour & Flu \\
\hline Untreated water & Intestinal infection & Bean husks & Catarrh \\
\hline Lack of basic sanitation & Gastritis & Corn flour & Risks \\
\hline Sewage & Related diseases & Filled biscuits & Can kill \\
\hline Rubbish & Flu & Chocolate during the hot season & Quick death \\
\hline Dirt & Catarrh & Eating out & Parasites kill \\
\hline Stench & Fatigue & Sausages & Dehydration kills \\
\hline Vectors & Risks & Fried chicken croquettes (Coxinha) & \\
\hline Parasites & Death & Snacks & \\
\hline Bacteria & & Environmental & \\
\hline Microbes & & Heat & \\
\hline Germs & & Pollution & \\
\hline Flies & & Untreated water & \\
\hline & & Rat or dog faeces & \\
\hline & & Flies on refuse & \\
\hline & & Refuse & \\
\hline & & Lack of basic sanitation & \\
\hline & & Lack of sceptic tank & \\
\hline & & Sewage & \\
\hline & & Dirt & \\
\hline & & Stench & \\
\hline & & Vectors & \\
\hline & & Parasites & \\
\hline & & Bacteria & \\
\hline & & Microbes & \\
\hline & & Viruses & \\
\hline & & Rats & \\
\hline
\end{tabular}


Table 5 Mothers perceived symptoms in dehydrated children and children with diarrhoea

\begin{tabular}{|c|c|c|c|}
\hline \multicolumn{2}{|l|}{ 1997-1998 } & \multicolumn{2}{|l|}{ 2003-2004 } \\
\hline Pain & Loss & Pain & Loss \\
\hline Belly & Loss of appetite & Belly & Loss of appetite \\
\hline Head & Not wanting water & Head & Weight loss \\
\hline Teeth & Weight loss & Intestinal & Getting thin \\
\hline Fever & Getting thin rapidly & Colic & Malnourished \\
\hline Strong & Loss of liquid & Suffering & Anaemic \\
\hline Head burning & Too much liquid loss & Fever & Loss of liquid \\
\hline Vomits & Body with no liquid & Fever & Loss of liquid \\
\hline Vomits & Dehydration & Vomits & Lack of liquid \\
\hline Crying & Behaviour changes & Vomits & Lack of liquid in the bowel \\
\hline Cries without tears & Weak & Crying & Dried up inside \\
\hline Faeces consistency & Awkward & Too much & Dehydrated \\
\hline Watery & Depressed & Faeces consistency & Behaviour changes \\
\hline Soft & Submissive & Pure water & Only wants liquid \\
\hline Viscous & Being a softie & Soft at all times & Weak \\
\hline Thin & Fatigued & Soft and sometimes bloody & Awkward \\
\hline Greasy & External signs & Thin & Submissive \\
\hline Foamy & Belly & Small blobs & Despondent \\
\hline Acute diarrhoea & Big-bellied & Strange & Sad \\
\hline Liquid diarrhoea & Wrinkled belly & Different & Different and strange \\
\hline Profound diarrhoea & Swollen belly & Faeces Colours & Restless \\
\hline Faeces Colours & Full of worms & Yellow & Smelly \\
\hline Yellowish & Skin & Green & Depressed \\
\hline With flecks of blood & Changes & Faeces Smells & Stretched out \\
\hline Greenish & Sticky & Bad smell & On mother's lap \\
\hline Faeces Smells & Face & Strange smell & Dizzy \\
\hline Smells bad & Pale & Terrible & Lifeless \\
\hline Strong & Eyes & Stinking & Dull \\
\hline Horrible & Sunken & Rotten & Not having sufficient strength to play \\
\hline Repugnant & Lips & Defecation & Not wanting to walk \\
\hline Fetid diarrhoea & Swollen and reddish & Frequency & Wanting to sleep all the time \\
\hline Defecation & Purple & All the time & Cannot be touched \\
\hline Frequency & Head & Over 3 days & In pain \\
\hline Two, four or five times a day & Sunken fontanel & Frequent and different & External signs \\
\hline More than four times a day & & Several times a day & Belly \\
\hline Every $5 \mathrm{~min}$ & & More than three times a day & Big-bellied \\
\hline Soft all the time & & More than four times a day & Skin \\
\hline Loose bowel & & Five or more times a day & Flaccid \\
\hline \multirow[t]{13}{*}{ Looks like running water } & & Every minute & Dry \\
\hline & & & All skin and bone \\
\hline & & & Grainy \\
\hline & & & Face \\
\hline & & & Pale \\
\hline & & & Droopy face \\
\hline & & & Eyes \\
\hline & & & Lazy \\
\hline & & & Sunken \\
\hline & & & Droopy \\
\hline & & & Dark circles under the eyes \\
\hline & & & Head \\
\hline & & & Sunken fontanel \\
\hline
\end{tabular}

treatments and the search for more efficient drugs to stop diarrhoea make many mothers believe they are not sufficiently effective. Some authors ${ }^{73}$ have indicated a certain resistance because of the image of saline solution as a treatment for the poor. They assert that this cheap and simple therapy is reinforced through the use of antibiotic pills, because it fails to stop diarrhoea at a time when mortality associated with this disease has been reduced (see online supplementary web table S2).

When we compared interview and ethnographic observation data from the first and second stages, a process of medicalisation in the discourse about hydration became apparent. In the first stage, the use of herbal teas and remedies was very diverse and 


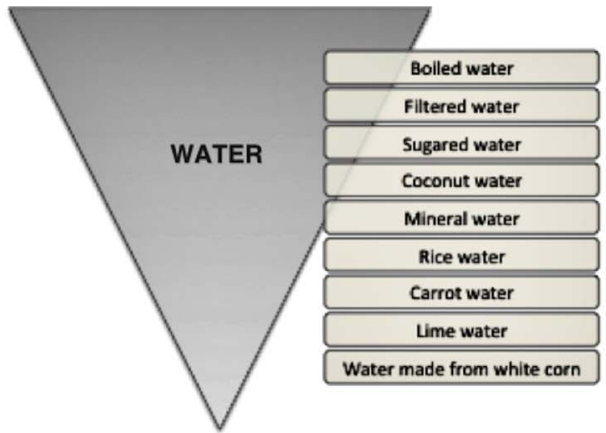

1997-98

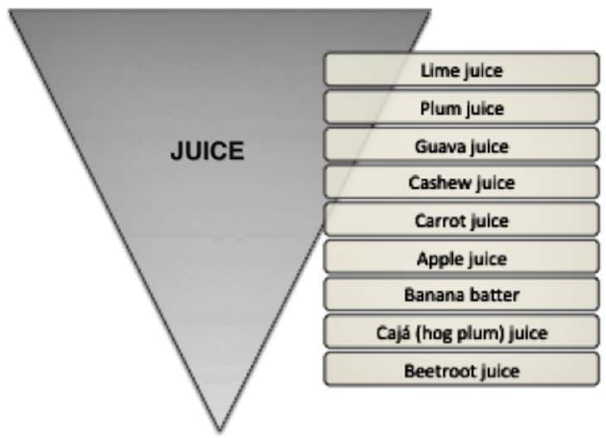

1997-98

Figure 1 Water and juice consumption during diarrheoa episodes.

some mothers even planted these herbs in their backyards (see online supplementary web table S3).

The preparation of these herbal teas is usually based on medicinal herbs (leaves, seeds, stems, flowers, peels, etc) and they also combined different kinds of herbs and medicines. By the second stage, traditional hydration practices such as herbal teas had decreased. Instead, there was an increased use of fruit juice and less-varied medical herbs.

Some of the plants had popularly acquired the names of actual drugs, such as anador, penicillin, dipyrone, benzetacil and novalgina. The practice of phytotherapeutic medicalisation was more widespread in the first stage of the study. Home remedies included a mixture of medicinal herbs, fruits and medicine. This therapeutic option was less prevalent by the second stage of the study. Greater complexity in the production of home remedies was replaced by a greater variety of drugs through increased self-medication.

This rapid process of medicalisation can be linked to certain changes that occurred in the neighbourhood: a reduction in childhood diarrhoea and parasitic infections following the installation of the sewage system, the implementation of the Family Health Program, the role of community health workers as mediators and the increased consumption of manufactured foods and beverages. Especially, this process is related to important reforms in Brazil. First, the social programme of the Federal Government Bolsa Familia, implemented from 2004, which consists of an economic aid to the families that receive less than 1 monthly salary and a half. Second, the progress of the Unified Health System, with the progressive development of the Family's Health Program from 1999.

\section{DISCUSSION}

The experience of loss of body water is related to cultural models of the body, humoral medicine (cold/hot polarity) ${ }^{74-76}$ and the child's behaviour in his or her daily life.
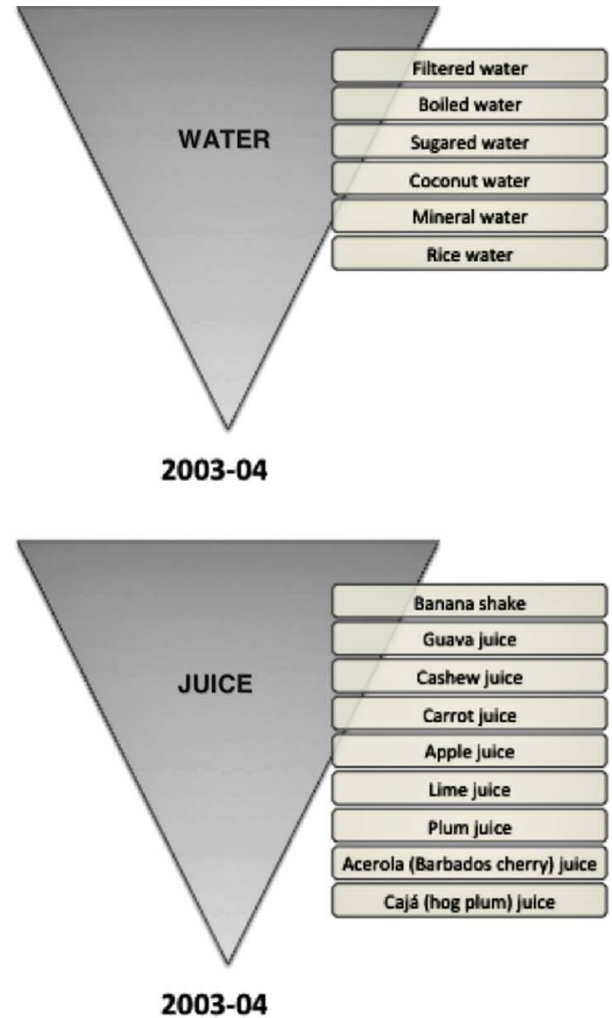

Dehydration is perceived as 'excessive loss'. This 'excess' is something that is exceptional, more than expected, out of place and no longer reasonable. In a social sphere in which shortage, for example, lack of food, money and basic infrastructure, is the usual experience, excess is difficult to imagine. But excess also causes diarrhoea: an 'excess' of spoilt food, of parasites, of dirt and refuse, etc.

Under these social and economic conditions 'excessive loss of water' means that the body is in great danger (eg, persistent diarrhoea). ${ }^{77}$ Perspiration is a normal indicator that removes body fluids due to physical exertion. Diarrhoea, however, accelerates loss of body fluids and, therefore, leads to an imbalance in the body. 'Excess' is due to quentura (excessive heat in the body or bowels), diarrhoea or warm weather. This naturalistic explanation about the origin of fluid loss refers to a process of naturalisation ${ }^{78}$ of the social causes that explain why fluid loss is perceived as a health risk. This kind of perception is related to social order and disease categorisation systems. ${ }^{79}$

Rehydration occurs upon recognition of a physical imbalance that can affect the child's health. This imbalance is recognised through several signs and symptoms, most notably the symbols related to bodily changes. The mothers' experience and perception of the notion of balance (the boundary between normality and pathology) is applied to the child's physical condition and behaviour and thus affects the choice and combination of home hydration therapies: medicinal herbal teas, vegetable or cereal water and fruit juices.

Water quenches thirst but fails to hydrate. This is why water needs to be manipulated and transformed. A liquid capable of hydrating is achieved through herbal teas mixed with sugar, boiled vegetables and fruit. These ways of turning water into a treatment to alleviate common diarrhoea constitute some of the self-care practices applied to these disorders. ${ }^{80}$ As with food 


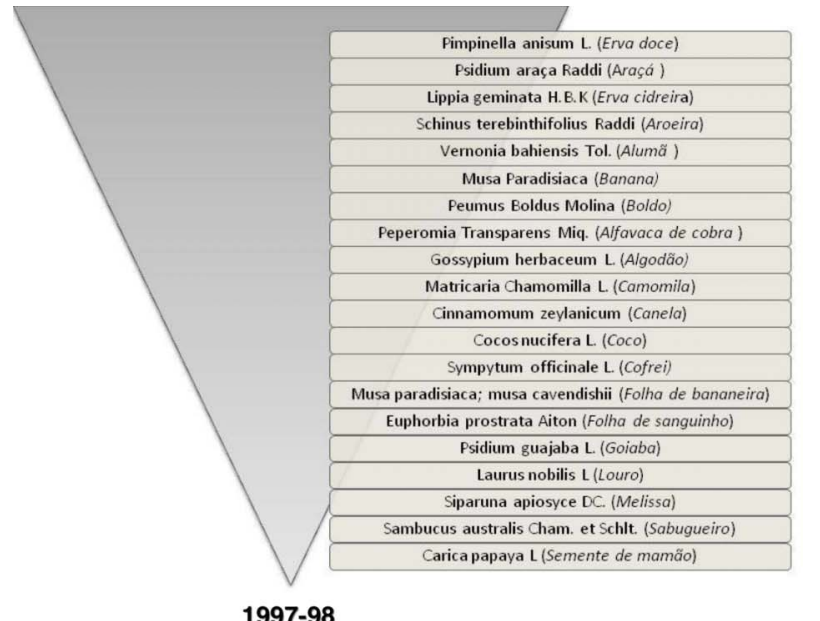

1997-98

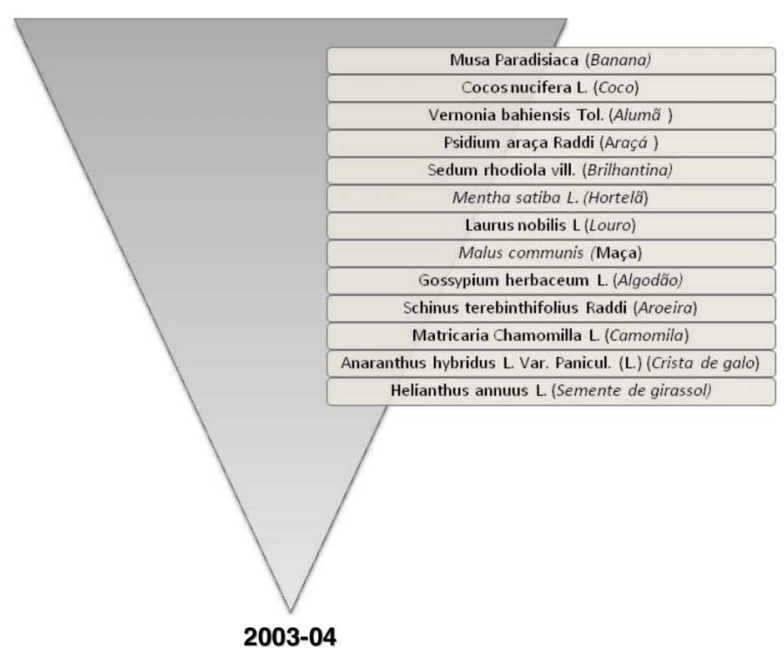

Figure 2 Herbal tea consumption during diarrhoea episodes (Scientific and common Portuguese names).

preparation, hydration is a cultural practice that implies some knowledge about water and about the herbs and vegetables that are able to restore the body's balance when it has been lost due to diarrhoea. Thus mothers learn how to turn water into a remedy that relieves and prepares the body for healing.

In our study, the difference between hydration and rehydration does not lie in the therapies employed, but rather in the meanings attached to these therapies and the ways they may be combined. The liquids used in hydration are care-oriented. Treatments usually involve changes in diet and increased liquid ingestion. However, rehydration implies an intensified combination of liquids, the use of saline solutions (homemade or supplied by health centres) and selfmedication practices using antibiotics. As the perception of severity increases, more liquids, saline solutions and drugs are added.

The process of medicalisation of traditional knowledge about dehydration has helped mothers to seek more effective remedies to control and stop diarrhoea and to enhance their children's mood and physical condition. For mothers, an effective drug should be able to stop the loss of fluids and the weakening process caused by diarrhoea, in the same way as vitamins. The dehydrated and weakened body represents a cultural image of shortage and the vulnerability of children ${ }^{81}$ that live in a context of great social inequality.
Table 6 Water, juice, herbal tea, drug and oral rehydration salt consumption during diarrhoea episodes

\begin{tabular}{ll}
\hline Water & Greater emphasis in the medical discourse about \\
dehydration makes mothers more concerned about the risk \\
of their children losing excessive liquid and they thus place \\
greater stress on the importance of drinking water, \\
especially during the second stage \\
Boiled water, which is used to prepare oral rehydration salts, \\
has turned into a home-made therapy for the treatment of \\
diarrhoea \\
Between the first and second stages we observed a \\
significant increase in the consumption of fruit juice to \\
reinforce the weakened child's diet \\
Fuice \\
Fild's energy than to heal the diarrhoea itself. This is why, \\
as we can see in figure 1, some of these juices are not \\
suitable for the treatment of diarrhoea \\
By the second stage, there had been a reduction of this \\
therapeutic option and a decrease in combining several \\
plants \\
Reduced complexity in the production of home remedies \\
was replaced by a greater variety of drug use through \\
self-medication \\
Increased consumption of various medications \\
(antidiarrhoeals, antibiotics, antipyretics, analgesics and \\
vitamin complexes) occurred in the second stage. This \\
practice responds to the search for therapeutic methods to \\
jointly cure diarrhoea and other symptoms, such as fever, \\
breathing problems and child weakness \\
Mothers give children these drugs alongside other home \\
remedies, rehydration salts and drinks to rehydrate the child \\
Oral rehydration therapy is so widespread that the oral \\
rehydration salt bundle starts to be called home-made oral \\
rehydration salts. It is not clear here whether the mothers \\
use the envelopes distributed by the health centre \\
(healthcare) or the water-based and sugar-based \\
composition that they can prepare themselves (self-care) \\
Drugs
\end{tabular}

\section{Box 1 Self-care and self-medication processes.}

- Hydration, unlike rehydration, is structural to self-care processes. This practice seeks to relieve a symptom or disorder through the development of a home remedy, while rehydration involves a specialised form of care focused on healing.

- Rehydration is associated with excessive dehydration perceived as a serious sign of diarrhoea.

- By the second phase, salts-based oral rehydration therapy was so widespread, both in distribution and preparation, that this practice had become a home remedy.

\section{What is already known about this subject}

- Thanks to an exhaustive review, we have observed that most anthropological studies of childhood diarrhoea that have addressed the issue of dehydration have adopted an ethnomedical approach with greater focus placed on an analysis of popular models for the classification of diarrhoea, local therapists' knowledge and the impact of oral rehydration therapy. 


\section{What does this study add}

- Our study explores the cultural models of the dehydrated body as well as hydration and rehydration from the mothers' perspective in a socioeconomic context of poverty. It takes into account an analysis of the use and combination of various alternative and home-made remedies, such as medicinal herbal teas; fruit juices; water from various cereals and boiled vegetables; and sweetened beverages, among others. Combining these therapies constitutes a set of structural practices for care, self-care and self-medication.

- The results of this qualitative study could be generalised to other periurban areas with similar socioeconomic characteristics and infrastructure (construction and implementation of sewage system, improvement of running water system and garbage collection), but the generalisations could not be extended to wider populations. Although a qualitative approach offers more richness and depth of understanding to this kind of researches, ${ }^{82}$ a weak point of this approach is that its results cannot be generalised as much as quantitative studies.

- A limitation to our research is that it does not evaluate the oral rehydration therapy programmes applied by the WHO in the past and its implications in periurban districts like this one.

- Our study may contribute to programmes of health promotion that take into account local cultural models on hydration and dehydration.

Acknowledgements The authors are especially thankful of the collaboration of Mauricio Barreto and Rita Rego, epidemiologists at the University Federal of Bahia, Brazil. They also thank all informants in the research for sharing their time and experiences.

Contributors The principal author of this paper has participated as ethnographer, acquiring the data and research coordinator. Both authors have contributed to the analysis and interpretation of data, the elaboration of the results and the creation of the tables and figures. Also both have been participants in drafting, writing, critically revising and finalising the manuscript.

Funding This study was supported by Pronex-Centres of Excellence Programme CNPq 661086/1998-4; Department of Infrastructure, State Government of Bahia; and a Visitant Professor Fellowship from CAPES Cristina Larrea in 2010.

Competing interests None.

Provenance and peer review Commissioned; externally peer reviewed.

\section{REFERENCES}

1 Almroth S, Latham MC. Rational home management of diarrhoea. Lancet 1995:345:709-11.

2 WHO. Replanteamiento de la atención infantil: supervivencia, crecimiento y desarrollo. Cap.6, 2005:111-32. http://www.who.int/whr/2005/08_chap6_es.pdf (accesed 18 Dec 2012).

3 Wolfheim C. From disease control to child health and development. World Health Forum 1998;19:174-81.

4 Munos M, Walker CL, Black RE. The effect of oral rehydration solution and recommended home fluids on diarrhoea mortality. Int J Epidemiol 2010;39:i75-87.

5 WHO. Centro de prensa. Son necesarias más investigaciones sobre la diarrea infantil. Identificadas nuevas áreas de investigación prioritarias. (Press release) 2009. http://www.who.int/mediacentre/news/releases/2009/diarrhoea_research_ 20090310/es/ (accesed 18 Dec 2012).

6 [No authors listed]. ORT and ORS: what is the difference? Glimpse 1994;16:15.

7 Coreil J, Mull D. Anthropological studies of diarrheal illness. Soc Sci Med 1988:27:1-3

8 Scrimshaw SCM, Hurtado E. Anthropological involvement in the Central American Diarrhoeal Disease Control Project. Soc Sci Med 1988;27:97-105.

9 Weiss MG. Cultural models of diarrhoeal illness: conceptual framework and review. Soc Sci Med 1988:27:5-16.
10 Scrimshaw SCM, Hurtado E. Procedimientos de asesoría rápida para programas de nutrición y atención primaria de salud. Enfoques antropológicos para mejorar la efectividad de los programas. Tokio: Universidad de las Naciones Unidas, 1988.

11 Bentley ME, Pelto GH, Straus WL, et al. Rapid ethnographic assessment: applications in a diarrhoea management program. Soc Sci Med 1988;27:107-16.

12 Kendall C, Foote D, Martorell R. Ethnomedicine and oral rehydration therapy: a case study of ethnomedical investigation and program planning. Soc Sci Med 1984;19:253-60.

13 Kendall C. The implementation of a diarrhoeal disease control program in Honduras: is it "selective primary health care" or "integrated primary health care" ? Soc Sci Med 1988;27:17-23

14 Coreil J. Innovation among Haitian healers: the adoption of oral rehydration therapy. In: Pillai VK, Shannon LW, McKim JL eds. Developing areas. A book of readings and research. Oxford: BERG, 1995:420-32.

15 Green EC. Traditional healers, mothers and childhood diarrhoeal disease in Swaziland: the interface of anthropology and health education. Soc Sci Med 1985;20:277-85

16 Nations M, Souza MA, Correia LL, et al. Los curanderos brasileños: promotores eficientes de la terapia de rehidratación oral y otras estrategias para la supervivencia infantil. Bol Oficina Sanit Panam 1989;107:1-21.

17 Nations M. Spirit possession to enteric pathogens: the role of traditional healing in diarrheal diseases control. Proceedings of the International Conference on Oral Rehydration Therapy; 7-10 June, 1983, Washington, DC: 48-52.

18 Coreil J, Genece E. Adoption of oral rehydration therapy among Haitian mothers. Soc Sci Med 1988;27:87-96.

19 Mull JD, Mull DS. Mother's concepts of childhood diarrhoea in Rural Pakistan: what ORT program planners should know. Soc Sci Med 1988;27:53-67.

20 Nichter M. From ARALU to ORS: Sinhalese perceptions of digestion, diarrhoea, and dehydration. Soc Sci Med 1988;27:39-52.

21 Nichter $\mathrm{M}$, ed. Health social science research on the study of diarrhoeal disease: a focus on dysentery. In: Anthropology and international health: South Asian cases studies. Dordrecht: Kluwer Academic Publishers, 1989:111-34.

22 Bentley M. The household management of childhood diarrhoea in rural North India. Soc Sci Med 1988:27:75-85.

23 Alvarez-Larrauri S. Las prácticas maternas frente a la enfermedad diarreica infantiles y la terapia de rehidratación oral. Salud Publica Mex 1988;40: 256-64.

24 McLean M, Brennan R, Hughes JM, et al. Etiología de la diarrea infantil y terapia de rehidratación oral en el nordeste de Brasil. Boletin Sanit Panam 1982;92:405-17.

25 Nations M, Rebhun L. Mystification of a simple solution: oral rehydration therapy in Northeast Brazil. Soc Sci Med 1988;27:25-38.

26 Scheper-Hughes N. Infant mortality and infant care: cultural and economic constraints on nurturing in Northeast Brazil. Soc Sci Med 1984;19:535-46.

27 Victoria CG, Olinto MTA, Barros FC, et al. Falling diarrhoea mortality in Northeastern Brazil: did ORT play a role? Health Policy Plan 1996;11:132-41.

28 Zodpey SP, Deshpande SG, Ughade SN, et al. Risk factors for development of dehydration in children aged under five who have acute watery diahrroea: a case-control study. Public Health 1998;112:233-6.

29 Nchoji Nkwi P. Perceptions and treatment of diarrhoeal diseases in Cameroon. J Diarrhoeal Dis Res 1994;12:35-41.

30 WHO. Información de Prensa. Para salud ambiental se necesita agua potable y saneamiento. Washington, DC, 6 June 2002. http://www.paho.org/spanish/dpi/100/ 100feature23.htm (accesed 18 Dec 2012).

31 Curtis V, Cairncross S, Yonli R. Review: domestic hygiene and diarrhoeapinpointing the problem. Trop Med Int Health 2000;5:22-32.

32 Jenkins $C$, Howard P. The use of ethnography and structured observations in the study of risk factors of transmission of diahrrea in highland Papua New Guinea. Med Anthropol 1992:15:1-16.

33 Nielsen M, Hoogvorst A, Konradsen F, et al. Childhood diarrhoea and hygiene: mother's perceptions and practices in the Punjab, Pakistan. Working Paper 25, Colombo, Sri Lanka: International Water Management Institute, 2001

34 Curtis V, Kanki B, Cousens S, et al. Evidence of behavior change following a hygiene promotion program in Burkina Faso. Bull World Health Organ 2009:79:518-27.

35 Borghi J, Guinness L, Ouedraogo J, et al. Is hygiene promotion cost-effective? A case study in Burkina Faso. Trop Med Int Health 2002;7:960-9.

36 Curtis V, Cairncross S. Effect of washing hands with soap on diarrhoea risk in the community: a systematic review. Lancet Infect Dis 2003:3:275-81.

37 Strina A, Cairncross S, Barreto ML, et al. Childhood diarrhoea and observed hygiene behaviour in Salvador, Brazil. Am J Epidemiol 2003;157:1032-8.

38 Curtis V, Kanki B, Mertens T, et al. Potties, pits and pipes: explain hygiene behavior in Burkina Faso. Soc Sci Med 1995;41:383-93.

39 Genser B, Strina A, Teles CA, et al. Risk factors for childhood diarrhoea incidence. Dyanmic analysis of a longitudinal study. Epidemiology 2006;17:658-67.

40 Rego RC, Barreto ML, Killinger CL. 0 que é lixo afinal? Como pensam mulheres residentes na periferia de um grande centro urbano. Cad Saúde Pública 2002:18:1583-98. 
41 Howteerakul N, Higginbotham N, Freeman S, et al. ORS is never enough: physician rationales for altering standard treatment guidelines when managing childhood diarrhoea in Thailand. Soc Sci Med 2003;57:1031-44.

42 Sastry N, Burgard S. The prevalence of diarrhoeal disease among Brazilian children: trends and differentials from 1986 to 1996. Soc Sci Med 2005;60:923-35.

43 Edgeworth $\mathrm{R}$, Collins AE. Self-care as response to diarrhoea in rural Bangladesh: empowered choice or enforced adoption? Soc Sci Med 2006;63:2686-97.

44 Machado MM, Lindsay AC, Mota GM, et al. A community perspective on changes in health related to diarrhea in northeastern Brazil. Food Nutr Bull 2011;32:103-11.

45 Halvorson SJ. Women's management of the household health environment: responding to childhood diarrhoea in the Northern Areas, Pakistan. Health Place 2004;10:43-58.

46 Ellis AA, Winch P, Daou Z, et al. Home management of childhood diarrhoea in southern Mali-implications for the introduction of zinc treatment. Soc Sci Med 2007;64:701-12

47 Mabilia M. The cultural context of childhood diarrhoea among Gogo infants. Anthropol Med 2000;7:191-208.

48 Menéndez E. Modelos de atención de los padecimientos: de exclusiones teóricas y articulaciones prácticas. Ciênc Saúde Coletiva 2003;8:185-207.

49 Barreto ML, Genser B, Strina A, et al. Effect of city-wide sanitation program in Northeast Brazil on intestinal parasites infection in young children. Environ Health Perspect 2010;118:1637-42.

50 Barreto ML, Genser B, Strina A, et al. Effect of city-wide sanitation program on reduction in rate of childhood diarrhoea in northeast Brazil: assessment by two cohort studies. Lancet 2007:370:1622-8.

51 Bustamante V, Trad L. Cuidando da saúde das crianças pequenas no contexto familiar: um estudo etnográfico com famílias de camadas populares. Ciênc Saúde Coletiva 2007:12:1175-84.

52 Rasselle D, Aquino E, Barreto ML. Reducing childhood mortality from diarrhoea and lower respiratory tract infections in Brazil. Pediatrics 2010;126:e534-40.

53 Bourdieu P. El sentido práctico. Madrid: Taurus, 1991.

54 Good B. Medicine, rationality, and experience: an anthropological perspective. New York: Cambridge University Press, 1994.

55 Kleinman A, Wang WZ, Li SC, et al. The social course of epilepsy: chronic illness as social experience in interior China. Soc Sci Med 1995;40:1319-30.

56 Lindenbaum S, Lock M, eds. Knowledge, power and practice. The anthropology of medicine and everyday life. Berkeley: University of California Press, 1993.

57 Kleinman A. Writing at the margin. Discourse between anthropology and medicine. Berkeley, Los Angeles, London: University of California Press, 1995.

58 Barreto ML, Strina A, Prado M, et al. Saneamento básico: impacto epidemiológico do Programa Bahia Azul. Bahia Analise \& Dados. Salvador SEl 1997;7:24-38.

59 Calvasina PG, Nations MK, Jorge MS, et al. "Franqueza de nascença": sentidos e significados culturais de impressões maternas na saúde infantil no Nordeste Brasileiro. Cad Saúde Pública 2007;23:371-80

60 Kleinman A. Patients and healers in the context of culture: an exploration of the borderland between anthropology, medicine, and psychiatry. Berkeley: University of California Press, 1980

61 Larrea-Killinger C. Health and sanitation. Environmental health and socio-cultural conditions in two favelas in the city of Salvador (Bahia). Med Anthropol 2001 $11-12: 331-52$
62 Larrea-Killinger C. Agua, Basuras y alcantarillado: reciprocidad y políticas ambientales en un suburbio brasileño. Endoxa: Series Filosóficas, UNED 2002;15:75-96.

63 Golafshani N. Understanding reliability and validity in qualitative research. Qual Rep 2003:8:597-607

64 Larrea-Killinger C, Barreto ML. Salud ambiental urbana: aproximaciones antropológicas y epidemiológicas sobre la evaluación de um programa de alcantarillado en un contexto de grandes desigualdades sociales. Quaderns de I'Institut Català d'Antropologia 2006;22:71-99.

65 WHO (World Health Organization). http://www.who.int/topics/diarrhoea/en/ (accessed 19 Nov 2012).

66 DaMatta R. A casa \& a rua. Rio de Janeiro: Rocco, 1997

67 Sachon W. Bebidas-tendencia en desarrollo: Brasil está eufórico con los refrescos. Sachon-Fachzaitschriftenarchiv ab 1998. http://fzarchiv.sachon.de/index.php? pdf=Fachzeitschriften/Getraenke-Fachzeitschriften/BBIE/2003/02_03/BBIE_02_ 03_Brasil_esta_euforico_con_los_refrescos.pdf (accessed 7 May 2012).

68 Canadean. BNA Brasil Relatório 2011-ABIR. Consumo de todas as bebidas comerciais 2005-2010.

69 Race K. "Frequent Sipping": bottled water, the will to health and the subject of hydration. Body Soc 2012;18:72-98

70 Claro RM, Levy RB, Popkin BM, et al. Sugar-sweetened beverage taxes in Brazil. Am J Public Health 2012;102:178-83.

71 Levy RB, Claro RM, Bandoni DH, et al. Availability of added sugars in Brazil: distribution, food sources and time trends. Rev Bras Epidemiol 2012;15:3-12.

72 Menéndez E. Intencionalidad, experiencia y función: la articulación de los saberes médicos. Rev Antropol Soc 2005;14:33-69.

73 Desjeaux D, Favre I, Simongiovanni J, et al. Why is oral therapy associated with drugs in the treatment of diarrhoea? J Pediatr Gastroentorology Nutr 1996:22:112-14

74 Pérez Férez JA. Hipócrates y los escritos hipocráticos: origen de la medicina científica. Epos: Rev filol 1986;2:157-75

75 Hipócrates. Tratados hipocráticos II: Sobre los humores. Madrid: Editorial Clásica Gredos, 1997

76 Foster GM. On the origin of humoral medicine in latin America. Med Anthropol Q 1987;1:355-93

77 Nations M. The child's disease (doença de criança): popular paradigm of persistent diarrhea? Acta Paediatr Supp/ 1992;381:55-65.

78 Douglas M. Símbolos naturales. Exploraciones en cosmología. Madrid: Alianza Editorial, 1978.

79 Douglas M. Purity and danger: an analysis of the concepts of pollution and taboo. London: Routledge and K. Paul, 1966.

80 Osorio RM. Entender y atender la enfermedad: los saberes maternos frente a los padecimientos infantiles. México, DF: Instituto Nacional Indigenista, CIESAS, CONACULTA. INAH, 2001.

81 Christensen PH. Childhood and the cultural constitution of vulnerable bodies. In: Prout A, ed. The body, childhood and society. London: Macmillan, 2000:38-59.

82 Bickman L, Rog DJ, eds. Handbook of applied social research methods. Thousand Oaks, CA: Sage, 1997 